\title{
Lechosław Tuz
}

\section{Microstructure evaluation of laser-welded 600 nickel alloy}

\section{Analiza mikrostruktury stopu niklu 600 spawanego wiązką lasera}

\begin{abstract}
This paper presents the results of a microstructure analysis of a laser butt-welded 600 nickel alloy. A microstructure evaluation of the joint is carried out with the use of light microscopy and scanning electron microscopy. The results indicate a phase $\gamma$ with some particles in the grain boundaries in the base metal. In the weld, a cellular-dendritic structure was observed.
\end{abstract}

Keywords: nickel alloys, laser welding, microstructure

\section{Streszczenie}

W pracy przedstawiono wyniki oceny mikrostruktury złączy spawanych stopu niklu 600. Do oceny struktury wykorzystano mikroskopię świetlną i skaningową mikroskopię elektronową. Uzyskane wyniki wskazują na występowanie w materiale rodzimym struktury fazy $y$ wraz z niewielką ilością wydzieleń po granicach ziarn. Struktura spoiny ma budowę dendrytyczno-komórkową bez widocznych wydzieleń po granicach.

Słowa kluczowe: stopy niklu, spawanie laserowe, mikrostruktura

\section{Introduction}

Due to their unique properties (namely, high strength, creep resistance at high temperatures [up to $1000^{\circ} \mathrm{C}$ ], and corrosion resistance in aggressive environments), nickel alloys hold a special place in the aviation and energy industries. Environmental protection and the associated need to reduce greenhouse gas emissions cause that increasing energy consumption induces the creation of new materials and technology that influence the increased efficiency of newly developed power units. This is accomplished by raising the

Lechosław Tuz Ph.D. Eng.: AGH University of Science and Technology, Faculty of Metals Engineering and Industrial Computer Science, Krakow, Poland; Ituz@agh.edu.pl 
operating parameters (temperature and pressure) up to ultra-supercritical (USC) levels. Such service conditions necessitate the use of alloys that have resistance to corrosion in an aggressive atmosphere (both wet and dry). Nickel alloys are able to fulfill these requirements [1]. It is important to carry out a detailed investigation of the microstructure and mechanical properties after varied processes, such metal forming, heat treatment, and welding. Among the many alloys, solid solution strengthened nickel alloys like $\mathrm{Ni}-\mathrm{Cr}$-Fe alloy 600 and $\mathrm{Ni}-\mathrm{Cr}-\mathrm{Co}-\mathrm{Mo}$ have achieved increased attention from the power industry (including nuclear applications). The chemical elements found in these alloys ensure the desired properties; namely, corrosion resistance in oxidizing (e.g., $\mathrm{Cr}$ ) or reducing (e.g., Mo) environments while simultaneously achieving a synergy effect [2]. During the welding in heat-affected zone (HAZ) due to high temperature, $\mathrm{M}_{6} \mathrm{C}_{,} \mathrm{M}_{23} \mathrm{C}_{6}$-type (chromium-rich) carbides, and topologically closed packed phase $\mu$ precipitates (molybdenum-rich) are formed. Additionally, in the microstructure of alloy 617 , an intermetallic phase $\gamma^{\prime}$ can be present due to the presence of aluminum. The creation of intergranular carbides is important due to the lowering of mechanical properties and corrosion resistance [3-5]. The presence of titanium and aluminum oxides results in a significant decrease in strength of alloy 617 , which can contribute to a higher susceptibility to hot cracking. Two major methods (and the most effective) for the welding of nickel alloys are gas tungsten arc welding (GTAW) and laser beam welding, which has been confirmed by many investigators. There are no studies on the technological parameters, microstructure, and mechanical properties of joints carried out by laser beam. In the GTAW process, heat input is much greater than in friction stir welding (FSW) and lower than in laser beam welding. This paper presents an investigation of the microstructure of laser beam welds. Relatively large heat input allows us to obtain a single pass butt weld without welding discontinuities.

\section{Experimental procedures}

The wrought nickel alloy 600 widely used in the energy industry on components operating at elevated temperatures and in aggressive corrosive environments was the base metal of the experiment. Application of this alloy results from its high mechanical properties in service temperature, creep, and oxidation resistance. A butt-welded 3-mm-thick joint was carried out in a robotic laser welding station. The laser processing parameters were as follows: laser power - $3.1 \mathrm{~kW}$; scanning speed $-1 \mathrm{~m} / \mathrm{min}$; and focused beam diameter $-0.2 \mathrm{~mm}$. Argon was used as a shielding gas for protecting the melt pool. The butt weld was first subjected to a visual inspection; then, a specimen from the cross-section was cut for microstructural analysis. Characterization of the microstructure of the autogenously welded joint was performed using light and scanning electron microscopy. 


\section{Results and discussion}

Laser beam welding was chosen because it ensures high power density and deep penetration, which allows us to avoid the beveling of relatively thick plates. In Figure 1, the joint in as-welded condition and cross-sectional macrostructure are presented. The face of the weld is characterized by a regular shape without excess weld metal and with a lack of undercuts. On the root side, welding discontinuities were not observed. The proper selection of welding parameters allow us to obtain a high quality in the joint. A macroscopic survey of the etched sample reveals a fusion zone with full penetration in an X-like shape.

The heat-affected zone was relatively narrow ( $0.5 \mathrm{~mm}$ near face and root side), but this was approximately $1.5 \mathrm{~mm}$ in the middle of the plate. In the middle, grain growth and microstructural changes in the segregation band were observed.

a)

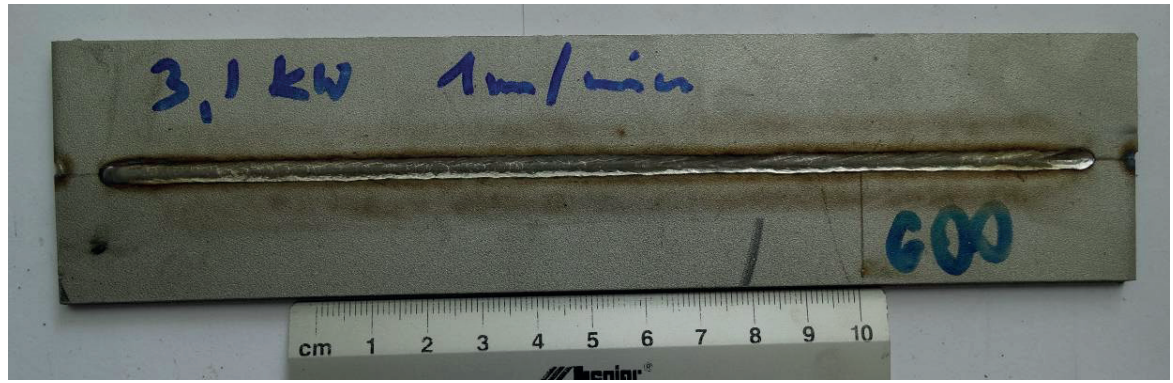

b)

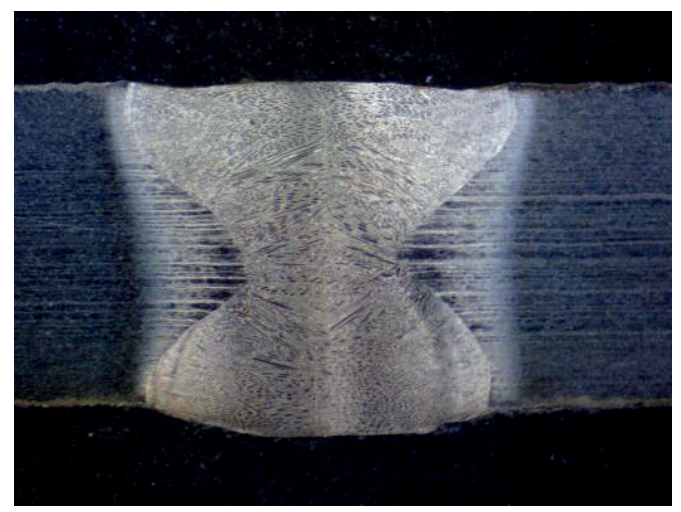

Fig. 1. Laser butt-welded plate of 600 nickel alloy: a) main view; b) macroscopic view, light microscopy 
Microscopic observations revealed a grain structure of the base metal with a mean grain size of approximately $40 \mu \mathrm{m}$ (Fig. 2a). The irregular distribution of chemical elements during the solidification of the billet caused that the size of the grains is different in the segregation bands; the biggest sizes were found in the broad bands. The grain boundaries of the base metal are clearly outlined (which is presented in Figures 2a and $2 \mathrm{~b}$ ). The precipitation process of the secondary phases in the HAZ did not occur, which is a result of the low heat input and rapid cooling of the single-pass weld. In the area adjacent to the fusion line (Fig. 2c), the crystal growth complies with the direction of the heating conduction of the base metal. The microstructure of the weld zone observed via light and scanning electron microscopy is typical due to the cellular-dendritic solidification mode of the liquid (Fig. 3).

a)

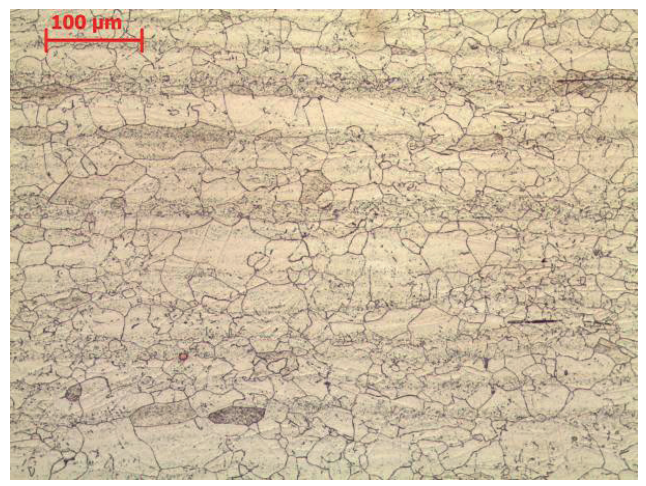

c)

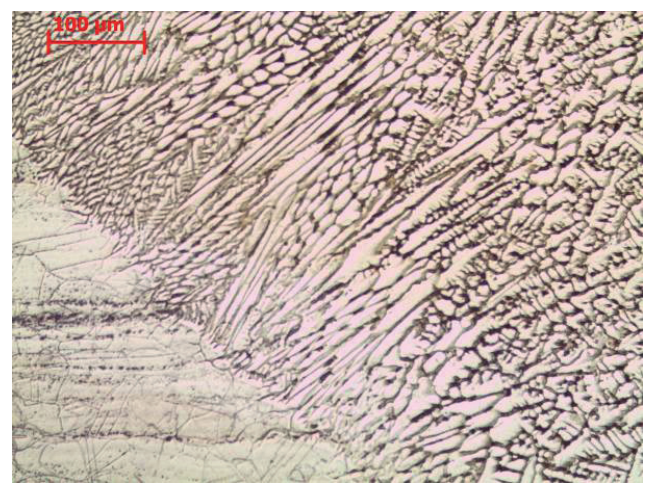

b)

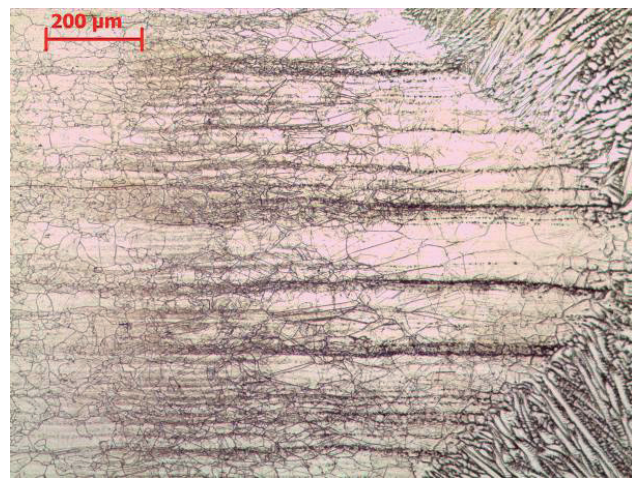

d)

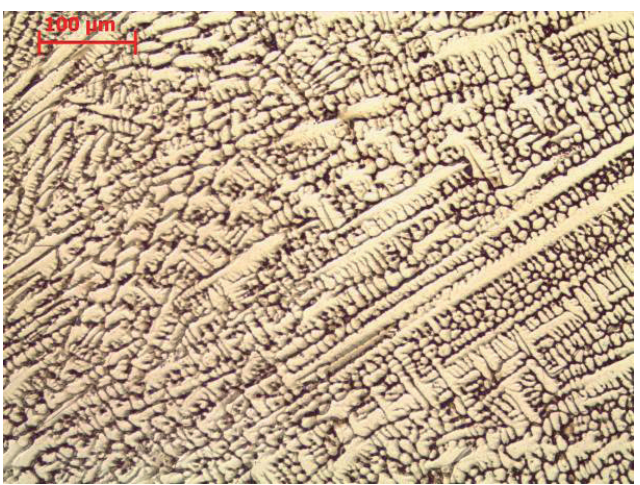

Fig. 2. Microstructure of welded joint, light microscopy: a) base metal; (b, c) HAZ; d) weld 
a)

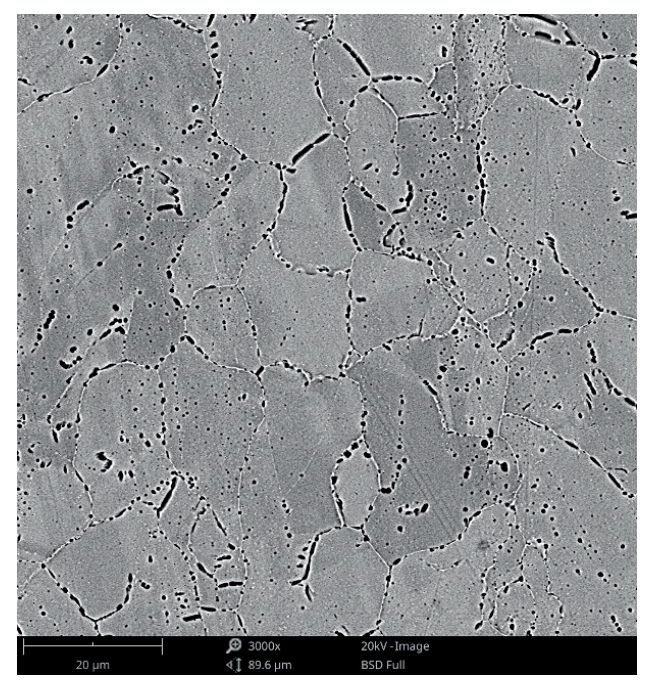

c)

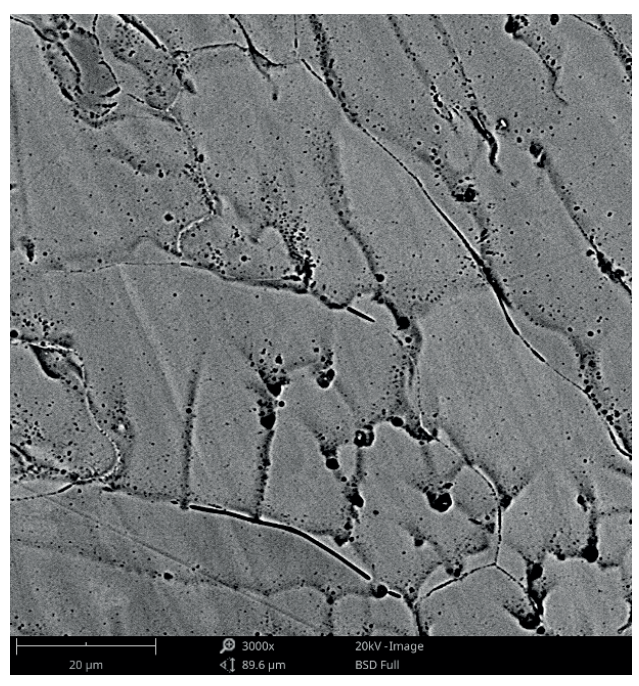

b)

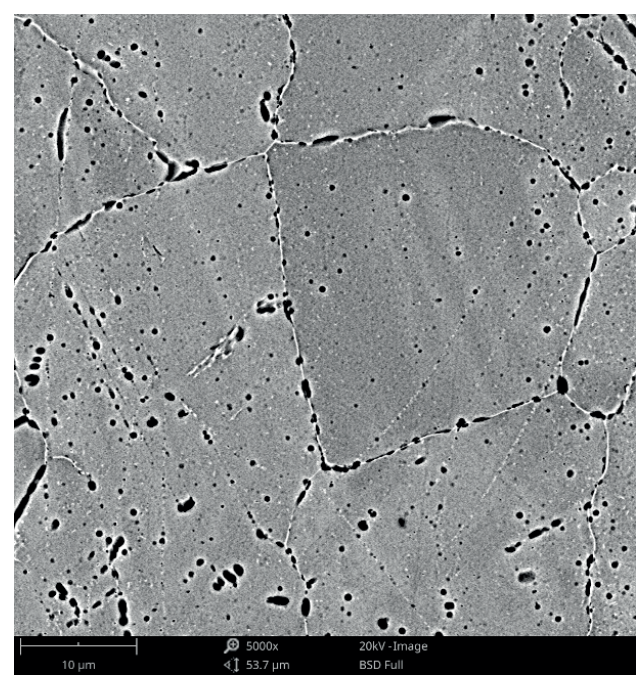

d)

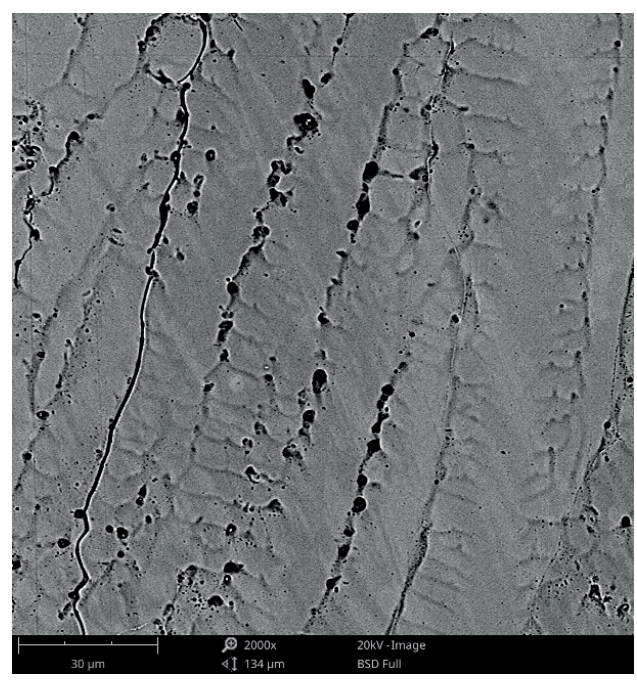

Fig. 3. Microstructure of welded joint, scanning electron microscopy: $(a, b)$ base metal; $(c, d)$ weld

\section{Summary}

On the basis of the conducted laser welding process and metallurgical investigation, it was found that the proper selection of welding parameters is a main issue to obtain full 
joint penetration and the favorable geometry of a weld. The high density of the molten metal and relatively low coefficient of the thermal conduction make that the HAZ is narrow. This is desirable; however, grain growth in the above-mentioned area can reduce the mechanical properties of the joint. The base metal in as-received condition consists of a $y$-matrix, a low volume fraction of secondary phase particles, and clearly visible segregation bands originating from the irregular distribution of the chemical elements during the solidification of the billet. The selection of welding parameters took into account the eventuality of constitutional liquation in the segregation bands. A too-high heat input can create the condition for the eutectic reaction of the second phase precipitates with the surrounding matrix below the equilibrium solidus temperature. These phenomena are detrimental to the properties of the $H A Z$, and they develop microfissuring under specific conditions. The fusion zone solidified via the cellular-dendritic mode with the privileged direction corresponding to the heating conduction of the surrounding base metal. In the middle of the weld, a transcrystallization zone with high metallurgical purity is visible. Although the crystallographic orientation of the crystals is changed in this region, it does not decrease the properties of the weld zone.

\section{Acknowledgements}

Research supported by grant no. 15.11.110.425.

\section{References}

[1] Ma Ch., Mei J., Peng Q., Deng P., Han E., Ke W.: Microstructure Characterization of the Fusion Zone of an Alloy 600-82 Weld Joint. Journal of Materials Science \& Technology, 31 (2015), 1011-1017

[2] Song K.H., Nakata K.: Effect of Precipitation on Post-heat-treated Inconel 625 Alloy after Friction Stir Welding. Materials and Design, 31 (2010), 2942-2947

[3] Yenia C., Koc-akb M.: Fracture Analysis of laser Beam Welded Superalloys Inconel 718 and 625 Using the Fitnet Procedure. International Journal of Pressure Vessels and Piping, 85 (2008), 532-539

[4] Yilbas B.S., Akhtar S.S., Karatas C.: Laser Surface Treatment of Inconel 718 Alloy: Thermal Stress Analysis. Optics and Lasers in Engineering, 48 (2010), 740-749

[5] Huang C.A., Wang T.H., Han W.C., Lee C.H.: A Study of the Galvanic Corrosion Behavior of Inconel 718 after Electron Beam Welding. Materials Chemistry and Physics, 104 (2007), 293-300 